Notre Dame Law School

NDLScholarship

Natural Law Forum

$1-1-1963$

\title{
Soviet Philosophy: Past and Present, and Prospects for the Future
}

J.M. Bochenski

Follow this and additional works at: http://scholarship.law.nd.edu/nd_naturallaw_forum Part of the Law Commons

\section{Recommended Citation}

Bochenski, J. M., "Soviet Philosophy: Past and Present, and Prospects for the Future" (1963). Natural Law Forum. Paper 91. http://scholarship.law.nd.edu/nd_naturallaw_forum/91

This Article is brought to you for free and open access by NDLScholarship. It has been accepted for inclusion in Natural Law Forum by an authorized administrator of NDLScholarship. For more information, please contact lawdr@nd.edu. 


\section{SOVIET PHILOSOPHY: PAST AND PRESENT, AND PROSPECTS FOR THE FUTURE*}

J. M. Bocheński

Soviet PHILOSOPHY is little studied in non-Communist countries. ${ }^{1}$ Yet it is the philosophy of a large country, it has numerous representatives, ${ }^{2}$ and it plays a far from negligible role in the life not only of the Soviet Union but also of the other Communist countries. Moreover, it appears that quite apart from its interest as a historical phenomenon and its political relevance, Soviet philosophy offers some interest for the philosopher as such.

I have thought it useful, therefore, to offer a short presentation of this philosophy for the use of those Western readers who may be interested in it either because of its historical interest or because of its intrinsic characteristics. Knowledge of the basic material tenets of Soviet philosophy is assumed here, ${ }^{3}$ and this presentation is limited to formal factors and to an appreciation of the level attained.

This article presents (I) a sketch of the history of Soviet philosophy; (II) a description of its organization and magnitude; (III) an evaluation of recent changes in general; (IV) an evaluation of the actual state of the single philosophical disciplines; and (V) the prospects for the future in the light of contemporary facts and trends.

* The author wishes to thank the members of the Institute of East-European Studies, especially Mr. K. Ballestrem, Dr. T. J. Blakeley, Mr. D. D. Comey, Dr. H. Fleisher, and Dr. S. Müller-Markus, for the suggestions and help received. Many insights referred to here in a brief form are due to long and arduous research by them.

The following abbreviations will be used in footnotes: SST for STUdies IN SovieT Thougrt; VF for Voprosy filosofil (Moscow, Institute of Philosophy of the Academy of Sciences of the USSR).

1. The Institute of East-European Studies at the University of Fribourg seems to be the only organized center of such studies. Neither in Europe nor in the United States is there, so far as I know, a single university chair entirely devoted to the study of Soviet philosophy. The number of Western specialists in this field is probably fewer than twenty.

2. See section II infra.

3. For expositions of the content of Soviet philosophy, see H. B. Acton, The IlLusion of the Epoch (1955); J. M. Bochenski, Der sowjetrussische dialektische Materialismus (3rd ed., 1960); Die dogmatischen Grundlagen der sowjetischen PhilosopHIE, in the Sovietica series (1959) (English translation forthcoming); G. A. WetTER, Dialectical Materialism (1958); Sowjetideologie heute (1962). 
The History (and prehistory) of Communist philosophy may be divided into three periods: the Marxian, the Leninist, and the Soviet. ${ }^{4}$ I shall limit analysis here to the third, which runs approximately from the death of Lenin to our time. This period is, in turn, usually subdivided into three sections:

The first, ending January 26, 1931, is a period of lively discussion; it is sometimes called "the first period of discussion."

The second, from January, 1931, to June 20,1947, is a period during which relatively little original thought was produced, at least in print. This period is sometimes called the "dead period"; and some will call it "Stalinist" in spite of the fact that it was Stalin himself who put an end to it in 1947.5

The third, from June 20,1947, on, is again a period of lively discussion. I shall call it "the second period of discussion." It covers the last six years of Stalin's lifetime, the interregnum, and the reign of Khrushchev. ${ }^{6}$

In the last period, the major events are the two ukazes of Stalin, one delivered through Zhdanov on June 24, 1947, ${ }^{7}$ the other contained in the widely publicized declarations on language and linguistics of June 20,1950.8

To understand the relevance of these two decrees, it must be understood that at that time the totality of Soviet philosophy - at least as expressed in print - was dominated by the principle of party-mindedness (partijnost), interpreted in a very narrow and extreme way. The principle itself, which is still basic in Soviet philosophy, holds that every philosophy is class-bound and, consequently, party-bound. ${ }^{9}$ From this position there was deduced, first, that everything in philosophy and in the sciences is of a party character: ${ }^{10}$ e.g., every sort of logic developed by the bourgeoisie had to be wrong; and the proletarians had to have a quite different, dialectical logic. ${ }^{11}$ Consequently, formal logic was condemned as erroncous. It was deduced, secondly, that as every class has only one party, there can be only one philosophical

4. Cf. J. M. Bocheński, On Soviet Studies, 1 SST 5ff. (1961).

5. At the beginning there was some philosophical life, especially in philosophy of physics and in history of philosophy. See David Joravsky, Soviet Marxism and Natural Science 1917-1932 (1961).

6. For a more detailed survey of this period, cf. J. M. Bocheński, Einführung in die sowjetische Philosophie der Gegenwart, Aus Politik und Zeitgeschich te 45-59 (1959). 7. Text in VF no. 1, 256-272 (1947). English translation in On the History of Philosophy, 4 Political Apfairs (1948).

8. Main texts in Pravda, June 20 and July 4, 1950; also in VF no. 1, 3-20 (1950).

9. So, e.g., the official OsNovy MARKsistskoj filosofin [Fundamentals of Marxist Philosophy] 35f. (Moscow, 1958).

10. The official Kratkij Filosofskij Slovar [Short Philosophical Dictionary] has in its second edition an article, The Party-Character of Science and Philosophy col. 210a.

11. Cf. id. at cols. 296b-297a. 
doctrine for each class, ${ }^{12}$ and hence there should be no disagreements among the proletarian (i.e., Soviet) philosophers. The result was that practically no discussion was tolerated.

The second of these deductions was discarded by Zhdanov speaking on behalf of Stalin. He said, in substance, that as dialectics persists under socialism, there are and should be contradictions among philosophers, and the discussion must continue. ${ }^{13}$ This position was rendered possible by the new doctrine of nonantagonistic contradictions, ${ }^{14}$ ascribed (erroneously, as it seems) to Mao Tse-tung, ${ }^{15}$ a doctrine which led to allowing discussions among Communist philosophers.

The declaration of Zhdanov had an immediate effect, not only, it seems, because it was an order, but also because the Soviet philosophers really wanted to have real work done. It was above all the merit of B. M. Kedrov, a thinking and courageous man, that the discussion became at once very lively. Too lively, the authorities judged, and Kedrov was dismissed after a time from the post of editor-in-chief of the only Soviet philosophical magazine then in existence, Voprosy filosofi (Questions of Philosophy), which had been founded at the meeting of 1947. But, in one form or another, the discussion continued from then on, with different degrees of freedom according to political circumstances.

Then, in June, 1950, Stalin intervened again. He said that language is not superstructure; consequently, it is not linked with the base; and this meant that it is neither class- nor party-bound. This conclusion was a still more radical breach with the past: for language is the very vehicle of what Hegel called "objective spirit" and what became in Marx's terminology the "forms of social consciousness." Once it was admitted that such an important factor in the spiritual life of society is not necessarily class-bound, the same could be said of its other sectors. In fact, the doctrine was extended in 1951 to $\operatorname{logic} ;^{16}$ in 1955 to physics; ${ }^{17}$ in 1958 to at least some elements of ethics. ${ }^{18}$ A considerable part of the sciences and at least some, mainly marginal, domains of philosophy were now free to develop without party control. Thus the first deduction from partijnost, that everything in philosophy has a party character, was also rejected.

12. Cf. op. cit. supra note 9 , at 490 .

13. VF no. 1,270 (1947).

14. Such contradictions are said to exist in a classless society. Cf. op. cit. supra note 9, at 277 .

15. I am indebted for this information to Professor K. A. Wittfogel. Cf. also A. C. Cohen, How Original is "Maoism"?, 10 Problems op Communism 34-42 (1961).

16. Cf. VF no. $6,113.149$ (1951).

17. Cf. VF no. 1, 134-138 (1955). A report on the discussion is in S. Müller-Markus, Einstein und die Sowjetphilosophie, in the Sovietica series (1960).

18. Cf. op. cit. supra note 9 , at 581 f. 
Many Soviet philosophers have done the best they could in these improved conditions. Since 1947 there has been a steadily progressing development of philosophy, in a meaning of the word very much akin to what we give it in the West.

The external organization and the quantitative dimensions of this philosophy are massive.

Scientific life in the Soviet Union is directed by the Academy of Sciences of the Soviet Union. The Academy has a department of Economic, Philosophic and Jurisprudential Sciences, and this department contains, among others, an Institute of Philosophy, presently directed by P. N. Fedoseev. Some of the major Soviet Republics (e.g., the Ukrainian, the White Russian, the Azerbaidzhanian — but not the RSFSR) possess their own Academies of Science. The Soviet Academy has also several extensions in distant centers (e.g., in Dagestan, Kazan, Komi, the Urals). The Institute of Philosophy of the Academy of Sciences of the Soviet Union is not, strictly speaking, the supreme organ of philosophy; there exists also an Academy of Social Sciences at the Central Committee of the Communist Party of the Soviet Union, which seems to play a considerable role as an organ of the official Party philosophy. The Institute, however, publishes the main review for philosophy, Voprosy filosofii.

As to the teaching of philosophy, we may distinguish, on one hand, the departments of philosophy at the universities, which have often a numerous staff and many chairs; on the other, the institutes (kafedry) of philosophy in other academic and technical schools, e.g., in the institutes for training of teachers, in military schools, in institutes of technology, schools for dramatic art, etc. The Ministry of Higher Education also publishes a magazine of philosophy, Filosofskie nauki (Philosophical Sciences).

The normal curriculum of a teacher or research worker in philosophy is as follows. On completing his university studies, he becomes an "aspirant" and works during three years or more under the tutorship of a professor. At the end of this period he passes examinations and presents a dissertation for the degree of "candidate in philosophical sciences," a degree that corresponds somewhat to the German Ph.D. in philosophy. The doctorate is a degree which relatively few scholars obtain, and then only after a long time; up till now many university professors have not had it, in spite of a general rule that they should.

The number of Soviet philosophers actively engaged in teaching and publishing is considerable. The present author estimated it as 2000 in 1959; 
this estimate was later confirmed from Soviet sources. ${ }^{19}$ At the moment, there must be still more, perhaps around 2200, which makes about one philosopher in 100,000 inhabitants of the Soviet Union, a proportion much higher than in most non-Communist countries.

The following figures may give an idea of the number of graduate students in philosophy. According to the published lists of titles of dissertations, the degrees of kandidat nauk in philosophy were conferred as follows: in 1947, 66; in 1948-1951 (year average), 80; in 1951 and 1952, 203; in 1953 and $1954,469.20$

As to publications, the Bibliographie der sowjetischen Philosophie ${ }^{21}$ gives, for the years 1947-56, 2234 titles - an average of 223 a year; for the two years 1957-58, 803, or 401 a year; while the issue for the years 1959-60 mentions 1308 titles, or a yearly average of 654 . This is a very rapid increase; part of it is illusory, simply being due to more sources having been made available to the authors of the Bibliographie. But there can be no doubt that Soviet philosophical literature is increasing quantitatively at a significant rate.

The number of copies printed of philosophical books is also very conconsiderable. The classic textbook, Osnovy marksistskoj flosofii, first published in 1958, has had, to date, a run of close of 2,000,000 copies; Lenin's Materialism and Empiriocriticism had, to 1959, 103 editions with 5,034,000 copies distributed. ${ }^{22}$

The following figures concerning the number of copies of the Voprosy flosofi are also rather impressive: 1947 (first issue of the year), 15,000; $1949,22,000 ; 1951,35,000 ; 1953,36,000 ; 1954-1957,50,000$ (average); $1959,30,200 ; 1961,27,100 ; 1962,28,500$.

The diminution of the number of copies in 1958 is linked with the increase from six issues a year to twelve; while the total volume of one year was 1,712 pages in 1957, it was increased to 2,300 in 1958. In 1958 the Ministry of Higher Education's philosophical magazine, Filosofskie nauki, was also founded. ${ }^{23}$ If one considers that a page of Voprosy flosofii corresponds to about two pages of a normal American magazine, he must admit that this magazine is, of journals professionally devoted to philosophy, the largest in the world, both in number of copies and in pages.

In addition to the two reviews there is a nearly regular flow of volumes

19. Cf. VF no. 3, 156-159 (1960) and 2 SST 64f. (1962).

20. Computed by T. J. Blakeley. Cf. Bocheński, loc. cit. supra note 6, para. 10.

21. Bibliographie der sowjetischen Philosophie, vol. I-II (1959); III (1962); IV (1963).

Compiled by T. J. Blakeley.

22. 14 NovYe RNIGI (1959).

23. It is published six times a year in about 3000 copies. 
gathering articles from a number of contributors. Thus, for example, while there is no journal of logic in the Soviet Union, there have been at least three such collaborative works (sborniki) published on formal logic. ${ }^{24}$

Soviet philosophy, quantitatively considered, is clearly one of the first, if not the first, in the world.

\section{III}

WE MAY NOW ASK what is the present state of Soviet philosophy in comparison with that before 1947? In other words, what changed in it, and what did not?

If we consider general attitude and style fifteen years ago the reader was mostly struck by three characteristics: Soviet philosophy at that time was written in an emotive style, to a point that it was often difficult to draw a distinction between academic philosophy and vulgar propaganda; it was aggressive in tone, constantly using insults when speaking of nonCommunist philosophers; and, to use an expression of Professor M. P. Baskin, these writings resembled specimens of "quotesmanship" (citatologia) rather than philosophical argument. ${ }^{25}$ They were full of quotations of the "classics," and most of what was not directly quoted consisted of commentaries on these texts. ${ }^{26}$

Now, none of these characteristics has disappeared from Soviet philosophy. There is still much emotiveness, aggressiveness and insult; "quotesmanship" is also sometimes present. But, on the whole, there is a considerable improvement in all respects. Here a distinction may perhaps be drawn between two groups of writers on philosophy: some seem to preserve the old style, while others usually write in a style which is nearly that found in ordinary American or European philosophical writings. Also a distinction should be made between the different parts of philosophy. Doctrines connected with historical materialism are usually expounded in a style more akin to the old one. On the whole, an improvement is present. An average article published in Voprosy filosofii or Filosofskie nauki or an average book on a special problem is now apt to be written according to Western standards: it is no longer emotive; it has no insults for adversaries; and it uses few quotations or none at all. Much is still to be done, and some writers who seem to be

24. Voprosy logiki [Questions of Logic] (Moscow, 1955); Logicheskie ISSLEdovanija [Logical Investigations] (Moscow, 1959); PRIMenenie LOGIKI $\mathbf{v}$ NAUKe I TEKHNiKe [Application of Logic to Science and Technology] (Moscow, 1960).

25. VF no. 1, 160a (1947).

26. For a statistical elaboration, cf. Bocheński, loc. cit. supra note 6, para. 14 . 
unable to learn good manners will have to leave the scene in order that Soviet philosophy may attain a tolerable level from that point of view; but those who write quite decently are no longer the exception.

So much for the style. As to fundamental methods and assumptions, older Soviet philosophy was conspicuous for at least four traits: (1) The "classics" played a predominant role in it. Even if the writing was not a simple commentary on "classical" texts or a collection of such texts, the truth of every statement made by these "classics" was assumed. Not a single attempt to oppose a statement in the classics is known in the older Soviet philosophy. The principal consequences of this "classicism" were "deductivism" - philosophy consisted in deductions from the classic statements, and the sciences were disregarded; a nearly complete lack of awareness of problems - everything seemed to have been solved by the classics; and a patent tendency to link every assertion or theory advanced with some of the "classical" utterances. (2) No distinction was made between ideology and philosophy in the technical meaning of the word, other than that stated by Lenin (i.e., that philosophy is only a "part of Marxism-Leninism"). The result was that even the most speculative problems of theoretical philosophy, such as the purely formal problems of logic, were greatly influenced by political considerations. (3) Most of the terms used were hopelessly vague, and there was seldom any attempt to clarify their meaning. (4) Finally, all philosophical disciplines were lumped together under the titles of "dialectical materialism" (diamat) and "historical materialism" (histomat), no attempt being made to draw a distinction between the various philosophical disciplines and fields of research. ${ }^{27}$

There are still many people writing philosophy in the Soviet Union who rigidly adhere to the old methods and assumptions. They believe that every utterance of a classic is a sacred truth, conceive philosophy as a sort of deductive science, blind to problems, disregard the data of sciences, and expound thoughts in connection with some "classical" doctrine. Such people usually make no distinction between philosophy and politics, operating with the most vague terms and vacuous sentences and seeing every philosophical problem as belonging to either diamat or histomat. One extreme example of such an attitude is (or was) A. A. Maximov, the impenitent "dogmatist," who was liquidated — intellectually - in 1955.28 But less extreme representatives are still alive and writing.

27. The Soviet philosophical method has been examined in a penetrating way in $\mathrm{T}$. J. Blakeley, Soviet Scholasticism, in the Sovietica series (1961).

28. He has not published anything since the condemnation in VF no. 1, 134-138 (1955). 
However, fundamental methods and assumptions are also changing. In varying degrees, the characteristic traits of past Soviet philosophy have altered. I shall review the extent of change in the four typical aspects.

1) As to the role of the classics, at least one of them, Engels, has been often flatly contradicted by Soviet philosophers. ${ }^{29}$ For many of them it is today an established truth that not every statement of Engels is correct. Nothing of the sort is said as to statements of Lenin or Marx. But that not all statements of Engels are considered as absolute truths is a notable progress. This does not mean that the fundamental doctrines of Engels have been openly rejected; on the contrary, the authors who reject one of his statements usually add that this particular sentence is not consistent with the body of doctrines professed by Engels himself. In other words, what seems to have happened here is this: instead of the assumption that every statement of Engels is true, it is now assumed that only the general spirit or the basic doctrine propounded by him is true. The change in this respect in curiously similar to that effected by the Sic et non of Abelard, the great medieval logician who was the first of his time to abandon complete allegiance to every statement of the Fathers of the Church, and to adopt instead an allegiance to the body of doctrines professed by them as a whole.

Still, one may object, this change is merely an advance from a primitive pre-Abelardian "theology" to a more refined "theology" still below the level of Aquinas. Soviet philosophy remains, as far as general method and forma mentis are concerned, much more like theology than like philosophy in the way we in the West have understood philosophy since Aquinas. ${ }^{30}$

But there are signs that this situation may not be expected to last. These signs can be best seen in contrast with the earlier attitude toward the "classics." In many writings today deductivism is far less apparent; there is a growing feeling that the sciences cannot be simply disregarded as irrelevant; the awareness of problems is far greater than before; and, finally, the number of articles and books in which no attempt whatsoever is made to link the research at hand with a "classical" theory increases steadily. Moreover and this is perhaps the crucial fact - there are at least some philosophers in the Soviet Union who seem to consider the "classics" as having only a

29. E.g., E. Kol'man (cf. Nikolaus Lobkowicz, Das Widerspruchsprinzip in Der Neueren sowjetischen Philosophie 55, in the Sovietica series [1959]) and E. A. Asratjan (cf. VF no. 5, 31ff. [1955]).

30. Cf. T. J. Blakeley, op. cit. supra note 27. 
historical importance. At least one text taking that position is known; and there are several writings written as if the classics did not exist. ${ }^{31}$

One should not overstress those developments. The "historicizing" of the classics is rather the exception, and the vast majority of the Soviet philosophers do not think of anything of the sort or, at least, have never expressed such thoughts. Yet, the trend is present.

2) There seems to be no explicit distinction between ideology and philosophy; on the contrary, the official texts, like Osnovy marksistskoj filosofii and Osnovy marksizma-leninizma, stress the unity of both, and most of Soviet philosophy is tainted by politics today as it was fifteen years ago. The situation here seems to be less promising than the changing attitude to the classics. However, there are reasons to believe that the distinction, if never made explicit, is slowly imposing itself on a certain number of Soviet philosophers. There are some writings which are genuinely philosophical, i.e., in which no argument is used other than one which may be used independently of any ideology. Then there are at least some philosophers who would like to disassociate historical materialism from dialectical materialism. As histomat is far more linked with politics and Communist faith in general than is diamat there may be in this tendency a germ of a future distinction between the two realms. Perhaps Soviet philosophers will reach, if they continue along this line, the Catholic view of the faith as norma negativa for philosophy, or even to the Thomistic distinction between faith, theology, and philosophy. But those are just possibilities for the future. As of now, no clear distinction between philosophy and ideology has been reached.

3 ) There is also progress in the differentiation of philosophical studies. Today everyone distinguishes at least the following branches of philosophy: logic, philosophy of science, ethics, esthetics, psychology, history of philosophy. Since 1956 there has been a special seminar for formal logic at Moscow State University, and a sociological society exists now in the Soviet Union. Moreover, even in fields where a special discipline is not officially recognized, the relative autonomy of some studies is implicitly admitted. One outstanding instance is ontology. Officially, it is just a part of dialectical materialism; there are, however, relatively many studies of a purely ontological character, especially on categories, written by Soviet philosophers. Another, less obvious instance, perhaps, is the general theory of value, on which there is at least one book. ${ }^{32}$

31. It would be easy to quote a number of such works; for obvious reasons it is, however, preferable not to do so.

32. V. P. Tugarinov, O cennostjakh zhizni i Kul'tury [On the Values of Life and Culture] (Moscow, 1960). Cf. the review by H. Fleischer, 2 SST $72-75$ (1962). 
4) Much progress has been made in the formulation of philosophical thought. This area of expression is even the one which has the most promising aspect in Soviet philosophy. Of course, what has been said above about different sorts of Soviet philosophers applies here also: while many are still writing in the old muddled style, a group of men, obviously desiring to reach more clarity, works intensely in order to obtain more precise formulations.

The general conclusion is, therefore, that both in terms of style and general attitude and in terms of the content, real progress has been achieved by Soviet philosophy during the last fifteen years or so, if progress is understood in the light of generally admitted philosophical criteria.

\section{IV}

The situation in the different sectors of philosophy appears now, in brief, to be as follows:

Logic.-Formal logic has been universally recognized as legitimate, and it is studied. The legitimacy of mathematical logic as the only contemporary scientific formal logic is recognized by a large group of philosophers. Much work is being done, above all in strictly formal logic, and also in the history and the philosophy of logic. On the whole, in spite of the persistence of much crudity and nonsense, the situation with the majority of Soviet philosophers does not seem to be worse, but rather better than it is in the Western countries of continental Europe. ${ }^{33}$

Ontology.-There is a growing recognition of this field, and several studies have been made on purely ontological problems, above all those of categories. In this field we notice a growing awareness of problems. Some

33. On mathematical logic in the Soviet Union, cf. S. A. Janovskaja, Mathematicheskaja logika $i$ osnounaja matematika [Mathematical Logic and Basic Mathematics] in 1 MAtEMATIKA V SSSR zA SOROK LET 13-120 (Moscow, 1959); G. Küng, Mathematical Logic in the Soviet Union 1917-47 and 1947-1957, 1 SST 39-43 (1961). On the general situation in logic: H. Dahm, Renaissance der formalen Logic, in 8 Ost-Probleme 254-267 (1957); J. M. Bocheński, Soviet Logic, 1 SST 29-38 (1961); D. D. Comey, Two Recent Soviet Conferences on Logic, 2 SST 21-36 (1962). See also A. A. Zinov'ev, $O$ rabote seminara po logike $v$ Institute Filosofi [On the Work of the Seminar for Logic at the Institute of Philosophy], VF no. 2, 167-172 (1958), reviewed by D. D. Comey and G. L. Kline in 24 Journal of Symbolic Logic 232-233 (1959). On philosophical problems of logic, cf. G. A. Volkov, Konferencija po voprosam protivorechij [Conference on Questions concerning Contradictions], VF no. 12, 163-173 (1958); and, above all, N. LoBkowicz, DAs WIDERSPRUCH SPRINZIP . . . o op. cit. supra note 29, which contains a German translation of some otherwise not available relevant texts and a general introduction to the field; A. A. Zinov'ev, Filosofskie problemy mnogoznachnoj logiki [Philosophical Problems of Many-valued Logic] (Moscow, 1960), reviewed by L. H. Hackstaff and J. M. Bocheński in 2 SST 37-48 (1962). 
not irrelevant work has been done. Here, Soviet philosophy is still far behind what has been achieved in Europe, but perhaps a comparison with English or American philosophy would not result in an unfavorable judgment for the Soviet thinkers. ${ }^{34}$

Epistemology.-Because of the unfortunate theses of the sovpadenie (coincidence) of logic, epistemology, and dialectic, the sector does not show a progress comparable to that in the two above-mentioned disciplines. But even here some work on details has been done recently. The level is still low. ${ }^{35}$

Metaphysics.-Astonishingly enough, this most dogmatically bound discipline has developed somewhat more than epistemology. There is at least one important novelty in Soviet philosophy in this realm: a number of studies on the theory of emergence, linked sometimes with the flat rejection of optimistic evolutionism as applied to the universe at large. ${ }^{36}$

Philosophy of physics.-A quite notable progress has been achieved, especially since 1950. Far more intensely, it seems, than any other philosophers, Soviet philosophers do collaborate with physicists. Many important problems have been hotly discussed both by them and by a group of philosophically trained physicists. It seems that there is actually no school of thinkers who have done more in this sector, from the point of view of realism, than the Soviet philosophers. ${ }^{37}$

Theory of value.-Very poorly developed indeed; just a small beginning.

Ethics.-The state of ethics is not brilliant. Little awareness of real problems seems to be present. Yet, some work is being done, ${ }^{38}$ and recently some interesting changes in basic attitudes (e.g., the admission of moral laws which transcend classes) have been noticed. ${ }^{39}$

Esthetics.-Given the notorious interest of the First Secretary of the Soviet Communist Party in art, we have here to deal with a dangerous subject, and the progress is very limited. However, there have been some discussions

34. Consider, e.g., M. M. Rozental \& G. M. Shtraks, Kategorit materialisticheskoj Dialektiki [Categories of Materialist Dialectics] (Moscow, 1956); V. P. Tugarinov, Sootnoshenie Kategori Dialekticheskogo materializma [The Correlation of the Categories of Dialectical Materialism] (Leningrad, 1956). For a bibliography and general report of the discussions, see H. Fleischer, On Categories in Soviet Philosophy, 1 SST 65.77 (1962); The Materiality of Matter, 2 SST 12-20 (1962); H. Dahm, Soviet Philosophy's Conception of "Basic Laws," "Order" and "Principles," 1 SST 52-63 (1961). 35. Cf. T. J. Blakeley, Is Epistemology Possible in Diamat?, 2 SST 95-103 (1962).

36. S. T. Meljukhin, O Dialektike Razvitija neorganichesko Prirody [On the Dialectics of the Development of Inorganic Nature] (Moscow, 1960).

37. S. Müller-Markus, Bibliography of Philosophical Articles, in Uspexi Fizicheskich NAuk, 2 SST 255-260 (1962); Die Organisation der sowjetischen Philosophie der Physik seit Dezember 1960, 2 SST 49-63 (1962); Einstein und die Sowjetphilosophie I, in the SoviETICA series (1960). Cf. Einstein and Soviet Philosophy, 1 SST 78-87 (1961).

38. Cf. R. T. DeGrorge, A Bibliography of Soviet Ethics, 3 SST (1963).

39. See op. cit. supra note 9 , at 581 . 
on relevant problems, ${ }^{40}$ and the translation of Ingarden's essays into Russian indicates that there are in the Soviet Union some serious philosophers of art. ${ }^{41}$

History of Philosophy.-There are a number of monographic studies on various ancient and modern philosophers which, without attaining a high level, are sometimes reasonably well written. ${ }^{42}$ The attempt made by the unfortunately large Soviet History of Philosophy to present its subject from a non-European point of view is certainly interesting. ${ }^{43}$

\section{V}

WHAT ARE THE PROSPECTS for the future? It is well known that every prognosis in such fields as this can be only tentative, its degree of probability being usually low and, even so, it can be made at all only with the assumption of a rather far-reaching invariance of basic conditions. In our case, the assumption is that there will be no violent interference with philosophy by political authorities. Such interference, it seems, is not very probable. The number of individuals who have received a thorough training in rational thinking is now so large in the Soviet Union that it does not seem likely that the political authorities could stop rational thought in philosophy altogether, even if they wished to do so.

But if we assume that no such interference or other disastrous event, such as a great war, will take place, then the prospects of Soviet philosophy must be said to be good: there is a relatively high probability that this philosophy will speedily develop, both methodologically and in regard to its results, for the better. Several reasons may be advanced for this conclusion.

First of all there are now in the Soviet Union many actively working philosophers. They are probably the largest national group in existence. It is sometimes stressed that quantity does not make for quality; yet while this is true, there is a sense in which quantity is the basis for quality. It is more likely that among one thousand philosophers ten really good workers will be present, than among one hundred. Of course, a genius may be produced even by a very small group; still, quantity is not irrelevant.

40. L. N. Stolovich, Ésteticheskoe v DejStvitel'Nosti I v iskusstve [The Esthetic in Reality and Art] (Moscow, 1959), and the discussion in VF (1961) no. 1, 114-124 and no. 5, 112-123; (1962) no. 1, 154-159 and no. 2, 110-120.

41. Cf. R. Ingarden, Issledovanija po Éstetike [Investigations in Esthetics] (Moscow, 1962).

42. E.g., no fewer than six books have been published on Kant and six on Hegel. The subject is studied in K. Ballestrem, Soviet Historiography of Philosophy, forthcoming in 3 SST no. 2 (1963).

43. IstorijA FILOsofn [History of Philosophy] (Moscow, I-II, 1957; III-IV, 1959; V, 1961). 
Then, there is among the Soviet philosophers - or at least among a part of them - an obvious desire to raise the level of information, method and thought in general. This desire has already borne some fruit in a few years. There is no reason to believe that the process will not be carried on.

There thus seems to be reason to believe that there will be a steady progress in Soviet philosophy as far as the level of thought is concerned. It would not be astonishing if this philosophy produced some important works. In any case, one thing is very probable: Soviet philosophy will increasingly. become a relevant factor in general philosophy, a factor with which other philosophers will have to reckon more than they have needed to up to now.

So much for the methodological level. There are, however, two other questions which occur in the same context: (1) What prospects are there that Soviet philosophy will become similar to ordinary non-Soviet philosophy in regard to its purely rational character, i.e., how far is there hope that this philosophy will detach itself progressively from ideology? (2) What are the chances that Soviet philosophers will develop a type of philosophy identical with or similar to one or another American or European philosophy? It is the second problem which seems to be of most interest for many nonCommunist thinkers, who always approach Soviet philosophy from their particular point of view as, of course, they must.

To answer this second question first, it looks as if there were relatively little chance of Soviet philosophers becoming, say, phenomenologists, existentialists, or positivists. There are some such trends in the Soviet Union, but they are the exceptions. The great majority of Soviet philosophers follow their own line of thought - and this is true not only of the vast class of the muddled aparatchiki of the agitprop department, but also of those philosophical writers who belong to the best among the Soviet thinkers. This situation is a historical fact, as far as the present is concerned. As to the future, we know from the history of philosophy that the disruption of a philosophical school does happen, but that it does not happen easily. Moreover, we know that major trends of thought such as materialism, Platonism, Aristotelianism, empiricism, and subjective idealism are in a certain sense "immortal": it is very difficult to destroy them once they have been expressed by capable philosophers. There is, therefore, much chance that Soviet philosophy as a type of philosophical thinking will go on for a considerable time, that the school will not disappear soon. It seems to the present writer that the opposite view cannot be seriously substantiated.

But our first question is a different one. Even while preserving its basic assumptions - e.g., its thoroughgoing epistemological realism and its historicism - Soviet philosophy could detach itself from ideology in that the 
authority of ideology and its exponents would no more be assumed, and that the philosophers would use rational methods only. It cannot be denied that this may happen. There is even, perhaps, a certain probability that it will happen at one time or another. However, we have by far too few elements to make any prediction of this sort; and a comparison with similar phenomena in other periods and other civilizations does not seem to offer any encouragement to making one. 